\title{
Reasons behind the rising rate of involuntary admissions under the Mental Health Act (1983): service use and cost impact.
}

Shubulade Smith, MD [co]; Rebecca Gate, MSc [co]; Kevin Ariyo, MSc; Rob Saunders, PhD; Clare Taylor, PhD; Kamaldeep Bhui, MD; Ifigeneia Mavranezouli, PhD; Margaret Heslin, PhD; Helen Greenwood, MSc; Hannah Matthews, PhD; Phoebe Barnett, MSc; Stephen Pilling, PhD.

\begin{abstract}
There has been a significant rise in the use of the Mental Health Act (1983) in England over the last 10 years. This includes both health-based Place of Safety detentions and involuntary admissions to NHS mental health facilities. Although these trends should clearly inform the implementation of mental health care and legislation, there is currently little understanding of what caused these increased rates. We therefore sought to explore potential underlying reasons for the increase in involuntary admissions and Place of Safety detentions and to ascertain the associated service costs.
\end{abstract}

We extracted publicly available data to ascertain the observed number of involuntary admissions (Section 2 or 3 ) and health-based Place of Safety detentions in England between 1999/2000 and 2015/2016. A simple regression analysis then enabled us to compare observed admission rates with predicted rates, between 2008/2009 and 2015/2016. This prediction model was based on observed figures before 2008 . We then generated a costing model for these rates and compared admission costs to alternative interventions. Finally, we added relevant covariates to the prediction model, to explore potential relationships with observed rates.

Since 2008/2009, there has been a marked increase in the number of involuntary admissions (38\%) and Place of Safety detentions (617\%). The analysis revealed that for involuntary admissions, the period of greatest increase occurred after 2012, two years after austerity measures were implemented. For Place of Safety detentions, substantial rises were seen from 2008/2009 to 2015/2016, coinciding with the economic recession. The rise in Place of Safety detentions may have been worsened by a reduction in mental health bed availability. During the study period, involuntary admissions are estimated to have cost the English NHS $£ 6.8$ billion; with a further $£ 120$ million spent on Place of Safety detentions. This is approximately $£ 597$ million greater than predicted, had involuntary admissions continued to change at pre-2008 rates.

We conclude that the rise in involuntary admissions, and to a lesser extent Place of Safety detentions, were associated with three specific impactful events: the economic recession, legislative changes and the impact of austerity measures on health and social care services. In addition to the extensive arguments presented elsewhere, there is also an urgent economic case for addressing this trend. 


\section{INTRODUCTION}

\subsection{Recent trends in mental health service use}

There has been an increase in the number of people in contact with mental health services in England over the past 20 years, with a marked increase in recent years. Figures indicate that 1,805,905 people were known to be in contact with secondary mental health and learning disabilities services at some point in 2015/16. Although the overall number of hospital admissions is declining, involuntary admissions under the Mental Health Act 1983 (amended 2007) and Place of Safety detentions have continued to rise (Bhui et al., 2003; Keown, Weich, Bhui, \& Scott, 2011; NHS Digital, 2016). This has disproportionately increased in certain areas (Care Quality Commission, 2018; Weich et al., 2017) and among ethnic minority populations (Bhui et al., 2003). There have been similar recent increases in various jurisdictions, including across Europe (Turnpenny, Petri, Finn, Beadle-Brown, \& Nyman, 2018) and North America (Lebenbaum, Chiu, Vigod, \& Kurdyak, 2018), although there is considerable variation.

\subsection{Proposed explanations for this increase: An unclear picture}

A range of local and national factors have been suggested (Care Quality Commission, 2018) as being responsible for the rising rates of involuntary admissions and Place of Safety detentions. These include changes in mental healthcare provision, bed management, demographic and social change, legal and policy developments, and data quality and reporting.

A series of key events have occurred within the last 20 years (Johnson, 2013) including the introduction of the Mental Capacity Act in 2005 (Jones, 2005) ; the widening of the definition of mental disorder in the 2007 amendments to the Mental Health Act (Care Quality Commission, 2018); the introduction of safeguards in 2009 to protect the rights of people lawfully deprived of their liberty (Deprivation of Liberty Standards; DoLS) and the 2014 court ruling that applied these safeguards to a larger number of people (Cheshire West ruling) (Penny \& Exworthy, 2015). These legislative changes have been followed by drives to improve delivery through guidance such as the MHA Code of Practice, (Department of Health, 2015) the 2014 Crisis Care Concordat, (Department of Health, 2014) the Bradley report (Department of Health, 2009), police guidance on health-based Places of Safety (HBPoS) (Department of Health, 2017) and the Mental Capacity Act (2005) Code of Practice (Department for Constitutional Affairs, 2016). More recently, the UK government responded to concerns that current legislation is having a negative impact on mental health care by commissioning the Independent Mental Health Act Review. (DHSC, 2018a, 2018b)

In England, the above legislative changes and increased rates of involuntary admissions and Place of Safety detentions have also occurred within the context of growing financial pressures on the NHS. As part of the National Service Frameworks from 1999 to 2010, measurable goals were set to improve mental health care in England (DHSC, 1999). During this time, capital funds were made available, primarily from central government, to fund mental health services, with the bulk spent from 1999/2000 to 2005/06. In real terms, there was a 47\% (6.7\% per year) increase in expenditure on adult mental health services during this period, of which one third was spent on community-based teams (The King's Fund, 2015). Following the global economic recession of 2008, austerity measures were introduced in 2010 which led to reductions in mental health investment (Mattheys, 2015). Despite policy initiatives such as The Five Year Forward View for Mental Health (Independent Mental Health Taskforce, 2016) (launched in 2016), recent analyses have indicated that many mental health trusts have received either limited 
increases or net decreases in funding since 2011(The Royal College of Psychiatrists, 2018). Between 1997 and 2009, total healthcare spending increased approximately 7.5\% per year, which reduced to $1.3 \%$ per year between 2010 to 2014 (Office for National Statistics, 2015). Even greater reductions in funding were seen across social care, housing and unemployment support, all of which may disproportionately affect those with mental health problems (Local Government Association, 2016). A decline in funding has been accompanied by growing pressures on the mental health workforce (Centre for Mental Health, 2018). Shortfalls and challenges in recruitment and retention are particularly apparent in mental health nursing (NHS Improvement, 2019) where there has been an 11\% drop in positions from 2009 to 2018 (NHS Digital, 2019).

\subsection{The contribution of the present study}

It has been suggested (Szmukler \& Weich, 2017) that the rising involuntary admission rates may be attributed to either inherent characteristics of mental health legislation, changes in mental health funding (influenced by austerity), or a combination of both. Our objective was to explore potential impactful events that may have contributed to unexpected changes in these rates. We assessed publicly available data on the rates of involuntary admissions and Place of Safety detentions to better understand their causes and impact. We compared observed rates with predicted rates (that is, what they would have been had they continued to increase at pre-Mental Health Act amendment and pre-recession rates) and estimated associated costs.

\section{METHODS}

\subsection{Population}

Annual Mental Health Act data on admissions or Place of Safety orders for NHS provider facilities in England were extracted from public records via the Health and Social Care Information Centre Omnibus KP90 collection (HSCIC, 2016). The KP90 collection (replaced by the Mental Health Services Data Set) was used to provide the Department of Health with all recorded uses of the Mental Health Act by organisations in England that are registered to provide mental health services. Data were collected from 31st March 1999 to 31st March 2016. All data were publicly available with no ethical approval required.

\subsection{Measures}

\section{Involuntary admissions}

We included the total number of admissions to NHS facilities for assessment (Section 2) or treatment (Section 3) under the Mental Health Act. Where available, subsequent conversions to Section 2 or 3 following informal admission or use of a Place of Safety detention were also included. To avoid duplication, we excluded the reinstatement of a section, for example after the revocation of a Community Treatment Order. We also excluded forensic detentions (imposed by the court and for transfers from prison to hospital), on the basis that the rate of these remained consistent throughout the period(NHS Digital, 2016).

\section{Place of Safety detentions}

We included all Place of Safety detentions under Section 135 and 136 (which set out police powers to take a person who appears to be 'suffering from a mental disorder' to a 'Place of Safety'). This gives the police the power to convey an individual from a public place (S136) or non-public place (S135) 
(Zigmond, 2012). Data for Place of Safety were only available for health-based settings and did not include the use of detentions in other settings, such as police custody.

\section{Secondary measures}

We also included annual statistics that we considered to be potentially relevant to involuntary admissions and Place of Safety detentions, if data was available for the entire reporting period. We used NHS England's KH03 dataset to derive daily bed availability statistics for mental health, general and acute, maternity and learning disability wards in England (NHS England, 2019a). This covered overnight beds only. We also derived statutory homelessness (decisions under the 1996 Housing Act) (Office for National Statistics, 2017b) and police staffing (Office for National Statistics, 2017a) statistics from published government resources, for England and England and Wales, respectively.

\subsection{Analysis}

We used 1999/2000 as the start of the study period for all analyses. Data for involuntary admissions and Place of Safety detentions were plotted on a graph for the years 1999/2000 to 2015/16. We were particularly interested in any changes in the rate of detentions following the 2007 amendments to the 1983 Mental Health Act (implemented in 2008), the economic recession (in 2008) and the beginning of austerity measures (in 2010).

We used a univariate linear regression to explore the potential impact of these events on admission rates. All calculations were carried out using Stata 15 (StrataCorp, 2017). First, we used the period 1999/2000 to $2007 / 08$ as an observation base on which to build our regression model for predicting involuntary admissions detentions from 2008/09 to 2015/16 (an 8-year period). Second, we built a model to predict Section 135 and Section 136 (Place of Safety detentions) for the same period. This provided us with 'predicted' rates for involuntary admissions and Place of Safety detentions - that is, what they would have been had they continued to increase at pre-recession and pre-Mental Health Act amendment rates (i.e. before 2007/08). We then compared observed and predicted trajectories of admissions and detentions with the years when potentially relevant events first occurred.

Finally, we added six other variables of interest (homelessness rates, police staffing and bed availability for mental health, general and acute, maternity and learning disability sectors) as covariates in a stepwise regression. These models explore significant predictors of observed involuntary admissions and Place of Safety detentions between 1999/2000 and 2015/16 (a 16-year period). We compared six candidate models, by estimating how accurately the models predicted post-2008 observed rates, how well they fit the data overall, and how precise they were in their predictions (Ledolter, 2013).

For predicted rates, minimum and maximum costs were calculated using 95\% prediction intervals (PIs) from our regression models. These provide a range of expected values for each year over the prediction period. PIs are considered to be more robust estimates than confidence intervals, as they account for both sampling variability (observed values) and prediction variability (new observations). Cost differences between observed and predicted rates were calculated per year across an 8-year period.

\subsection{Spending and resource use data}

Unit costs were derived from the perspective of the national delivery of mental health care in NHS services in England, with methodological guidance from M.H. See Table A.1 (Appendix A) for a full 
overview of costing methodology. We used national data from the Personal Social Services Research Unit (PSSRU) (Curtis L, 2017) to estimate the cost (reported in pounds sterling at 2016/17 prices) of involuntary admissions and Place of Safety detentions. An involuntary admission was defined as a Mental Health Act assessment and a mean length of stay of 45 days, which was derived from NHS benchmarking data on the average length of stay for involuntary admissions across the country (S. Watkins, 2017). We assumed the average length of time for each type of assessment based on the clinical expertise of S.S and S.P. The total cost of Place of Safety detentions was adjusted according to the proportion of people who converted to Section 2 or 3 each year (see Table A.3; Appendix A). Unit costs of informal admissions and crisis resolution and home treatment were derived based on unit costs from the PSSRU (Curtis L, 2017) and NHS benchmarking data. (S. Watkins, 2017) (NHS Digital, 2016)

\section{RESULTS}

\subsection{Rates of involuntary admissions and Place of Safety detentions}

Between $1999 / 2000$ to $2015 / 16$ there was a $38 \%$ increase in the total number of involuntary admissions to NHS facilities $(38,985$ to 53,801). The number of involuntary admissions for assessment under Section 2 increased by 97\%, from 20,503 to 40,380, whereas Section 3 detentions for treatment decreased within this time period (by $29 \%$, from 18,470 to 13,205 ). Over the same period 1999/2000 to 2015/16, there has also been a marked increase (617\%) in hospital-based Place of Safety detentions (from 2,880 to 23,521). In 2015/16, the majority of Place of Safety detentions (22,965) were Section 136 detentions and only 17\% of these were converted to an involuntary admission. There were no available data on conversion rates from Section 135.

Figure 1 (below) plots the predicted rates, with the 95\% lower (LPI) and upper (UPI) prediction bounds, against the actual observed rates, clearly illustrating the extent of divergence. The $\mathrm{x}$ axis shows the timing of various potential impactful events for comparison, with further detail provided in Table A.2 (Appendix A). 


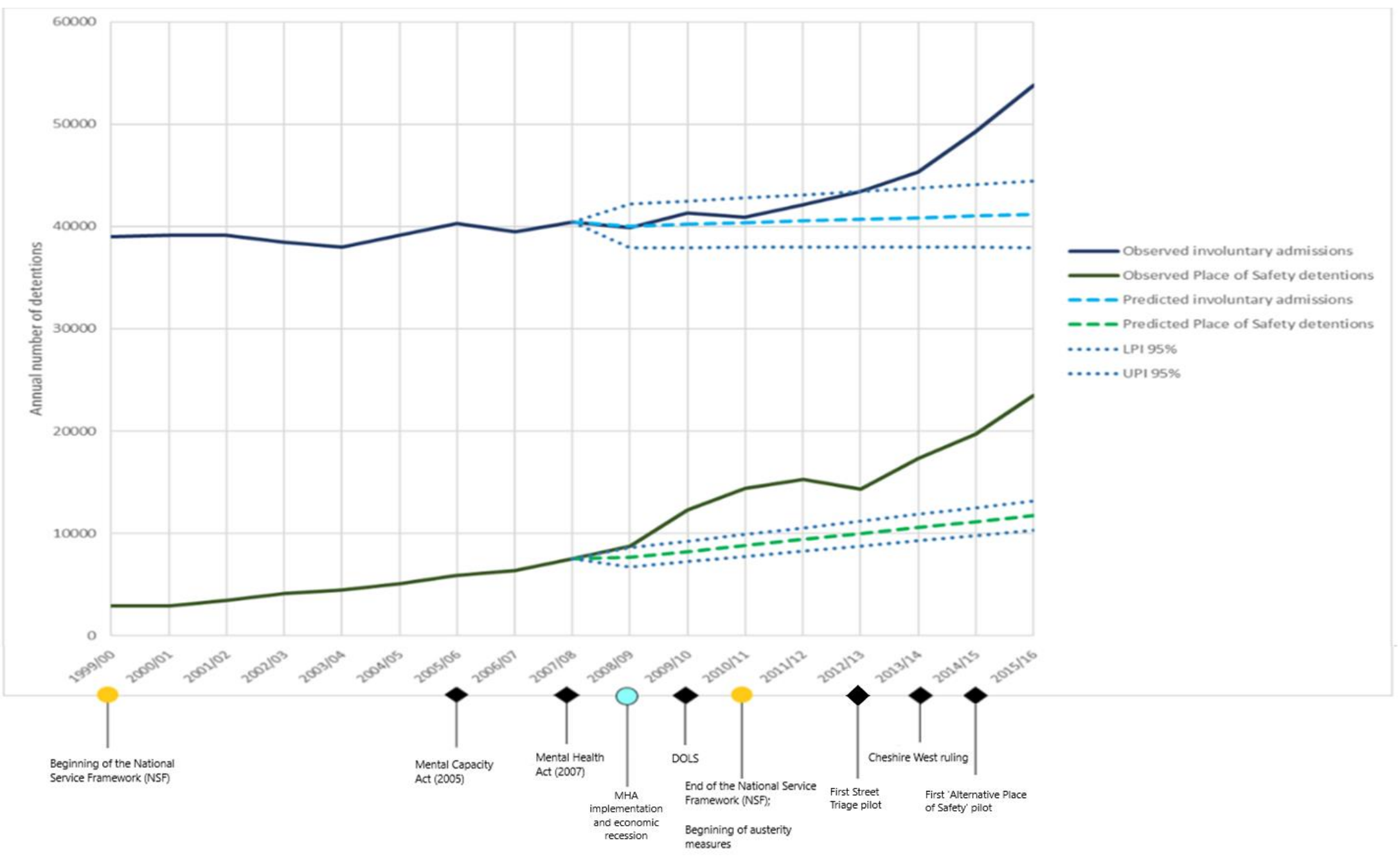

Figure 1: Observed and predicted rates of involuntary admissions and Place of Safety detentions 1999/2000 to 2015/201 


\begin{tabular}{|c|c|c|c|c|}
\hline \multirow[b]{2}{*}{ Year } & \multicolumn{2}{|c|}{ Involuntary admissions } & \multicolumn{2}{|c|}{ Place of Safety detentions } \\
\hline & Observed rate & $\begin{array}{c}\text { Predicted rate } \\
\text { Average [95\% LPI to UPI] }\end{array}$ & Observed rate & $\begin{array}{c}\text { Predicted rate } \\
\text { Average [95\% LPI to } \\
\text { UPI] }\end{array}$ \\
\hline $1999 / 2000$ & 38,985 & - & 2,880 & - \\
\hline $2000 / 2001$ & 39,160 & - & 2,925 & - \\
\hline $2001 / 2002$ & 39,117 & - & 3,405 & - \\
\hline $2002 / 2003$ & 38,480 & - & 4,101 & - \\
\hline $2003 / 2004$ & 38,005 & - & 4,443 & - \\
\hline $2004 / 2005$ & 39,113 & - & 5,079 & - \\
\hline $2005 / 2006$ & 40,266 & - & 5,877 & - \\
\hline $2006 / 2007$ & 39,488 & - & 6,387 & - \\
\hline $2007 / 2008$ & 40,469 & - & 7,538 & - \\
\hline $2008 / 2009$ & 39,922 & $40,052[37,900$ to 42,205$]$ & 8,759 & $7,649[6,692$ to 8,606$]$ \\
\hline $2009 / 2010$ & 41,311 & $40,217[37,939$ to 42,494$]$ & 12,300 & $8,231[7,219$ to 9,244$]$ \\
\hline $2010 / 2011$ & 40,899 & $40,381[37,963$ to 42,798$]$ & 14,399 & $8,814[7,739$ to 9,888$]$ \\
\hline $2011 / 2012$ & 42,112 & $40,545[37,975$ to 43,115$]$ & 15,240 & $9,396[8,253$ to 10,538$]$ \\
\hline $2012 / 2013$ & 43,461 & $40,709[37,977$ to 43,441$]$ & 14,296 & $9,978[8,764$ to 11,193$]$ \\
\hline $2013 / 2014$ & 45,348 & $40,873[37,971$ to 43,775$]$ & 17,315 & $10,561[9,270$ to 11,851$]$ \\
\hline $2014 / 2015$ & 49,261 & $41,037[37,958$ to 44,117$]$ & 19,718 & $11,143[9,774$ to 12,512$]$ \\
\hline $2015 / 2016$ & 53,801 & $41,202[37,939$ to 44,465$]$ & 23,521 & $11,725[10,275$ to 13,176$]$ \\
\hline $\begin{array}{c}\text { Total } \\
\text { increase } \\
(\% \text { increase })\end{array}$ & $14,816(+38.00 \%)$ & $2,217(+5.69 \%)$ & $\begin{array}{c}20,641 \\
(+616.70 \%)\end{array}$ & $8,845(+307.12 \%)$ \\
\hline
\end{tabular}

Table 1: Observed and predicted numbers of involuntary admissions to NHS facilities and Place of Safety detentions $1999 / 2000$ to $2015 / 2016$ 


\subsection{Costs of involuntary admissions and Place of Safety detentions}

Annual estimated costs for observed involuntary admission ranged from $£ 765$ million in 2008/09 to $£ 1.0$ billion in 2015/16 (See Table 2). Across the 8-year period, the total estimated cost of involuntary admissions was $£ 6.8$ billion. In contrast, average estimated costs for predicted involuntary admissions ranged from $£ 768$ million in $2008 / 09$ to $£ 790$ million in $2015 / 16$, with a total predicted cost of $£ 6.2$ billion. The greatest difference was found in 2015/16 when $£ 266$ million (or 35\%) more was spent on involuntary admissions. Decreasing the rate of observed involuntary admissions to those predicted would have resulted in an estimated 10\% cost reduction (approximately $£ 597$ million). Those not admitted involuntarily would have nevertheless required alternative care, such as additional mental health care over and above usual community care. Alternative crisis care, which may comprise informal admission or crisis resolution and home treatment, was estimated to cost $£ 405$ million and $£ 130$ million between 2008/09 and 2015/16, respectively. Therefore, even accounting for alternative care represents a cost saving ranging from $£ 191$ million to $£ 431$ million (See Table 3).

The estimated average annual spend on Place of Safety detentions increased every year, from $£ 9$ million in 2008/09 to $£ 23$ million in 2015/16. This estimate included the cost of a Mental Health Act assessment (assumed where the detention converted to an involuntary admission) and the lesser cost of a crisis assessment. The total estimated cost of observed Place of Safety detentions across the 8-year period was $£ 120$ million. The cost of predicted Place of Safety detentions was considerably lower, with a total estimated cost across the 8-year period of $£ 74$ million. This is approximately $£ 46$ million (or $38 \%$ ) lower than estimated actual spending. The greatest difference between costs was in 2015/16, where estimated costs of observed Place of Safety detentions were double the price of predicted ones.

Also see Table A.1 (Appendix A) for an outline of our costing model. 


\begin{tabular}{|c|c|c|c|c|}
\hline \multirow{2}{*}{ Year } & \multicolumn{2}{|c|}{$\begin{array}{l}\text { Cost of involuntary admissions } \\
\qquad(\mathfrak{f} \text { million })\end{array}$} & \multicolumn{2}{|c|}{$\begin{array}{l}\text { Cost of Place of Safety detentions } \\
\qquad(£ \text { million })\end{array}$} \\
\hline & $\begin{array}{c}\text { Observed } \\
\text { cost }\end{array}$ & $\begin{array}{l}\text { Predicted cost } \\
\text { (range) }\end{array}$ & Observed cost & $\begin{array}{l}\text { Predicted cost } \\
\text { (range) }\end{array}$ \\
\hline $2008 / 2009$ & $£ 765.74$ & $£ 768.24(£ 726.96-£ 809.53)$ & $£ 8.51$ & $£ 7.43(£ 6.99-£ 7.87)$ \\
\hline $2009 / 2010$ & $£ 792.39$ & $£ 771.39(£ 727.70-£ 815.08)$ & $£ 11.75$ & $£ 7.86(£ 7.30-£ 8.42)$ \\
\hline $2010 / 2011$ & $£ 784.48$ & $£ 774.54(£ 728.17-£ 820.92)$ & $£ 13.80$ & $£ 8.45(£ 7.87-£ 9.02)$ \\
\hline $2011 / 2012$ & $£ 807.75$ & $£ 777.69(£ 728.40-£ 826.98)$ & $£ 14.63$ & $£ 9.02(£ 8.42-£ 9.62)$ \\
\hline $2012 / 2013$ & $£ 833.63$ & $£ 780.84(£ 728.44-833.24)$ & $£ 13.72$ & $£ 9.58(£ 8.94-£ 10.22)$ \\
\hline $2013 / 2014$ & $£ 869.82$ & $£ 783.99(£ 728.32-£ 839.66)$ & $£ 16.60$ & $£ 10.13(£ 9.43-10.82)$ \\
\hline $2014 / 2015$ & $£ 944.88$ & $£ 787.14(£ 728.07-846.21)$ & $£ 18.87$ & $£ 10.67(£ 9.92-11.41)$ \\
\hline $2015 / 2016$ & $£ 1,031.96$ & $£ 790.29(£ 727.70-£ 852.87)$ & $£ 22.62$ & $£ 11.28(£ 10.52-£ 12.03)$ \\
\hline Total & $£ 6,830.64$ & $\begin{array}{c}£ 6,234.13(£ 5823.77 \text { - } \\
£ 6,644.49)\end{array}$ & $£ 120.49$ & $£ 74.40(£ 69.38-£ 79.42)$ \\
\hline
\end{tabular}

*Range calculated using upper and lower prediction intervals.

Table 2: Cost of involuntary admissions and Place of Safety detentions (observed and predicted) $2008 / 2009$ to $2015 / 2016$ 


\begin{tabular}{|c|c|c|c|c|c|}
\hline \multirow{2}{*}{ Year } & \multirow{2}{*}{$\begin{array}{c}\text { Number of } \\
\text { people } \\
\text { involuntarily } \\
\text { detained above } \\
\text { predicted levels }\end{array}$} & \multicolumn{2}{|c|}{$\begin{array}{l}\text { Informal admissions } \\
\qquad(£ \text { million })\end{array}$} & \multicolumn{2}{|c|}{$\begin{array}{l}\text { Crisis Resolution and Home Treatment } \\
\qquad(\mathfrak{f} \text { million) }\end{array}$} \\
\hline & & Predicted Cost & $\begin{array}{l}\text { Predicted cost } \\
\text { saving }\end{array}$ & Predicted cost & $\begin{array}{l}\text { Predicted cost } \\
\text { saving }\end{array}$ \\
\hline $\begin{array}{l}2008 / \\
2009\end{array}$ & $-130 *$ & $\begin{array}{c}-£ 1.70 \\
(-£ 29.73-£ 26.34)\end{array}$ & $\begin{array}{c}-£ 0.80 \\
(-£ 14.05-£ 12.45)\end{array}$ & $\begin{array}{c}-£ 0.63 \\
(-£ 11.09-£ 9.83)\end{array}$ & $\begin{array}{c}-£ 1.87 \\
(-£ 32.69-£ 28.96)\end{array}$ \\
\hline $\begin{array}{l}2009 / \\
2010\end{array}$ & 1,094 & $\begin{array}{c}£ 14.25 \\
(-£ 15.41-£ 43.92)\end{array}$ & $\begin{array}{c}£ 6.74 \\
(-£ 7.29-£ 20.76)\end{array}$ & $\begin{array}{c}£ 5.32 \\
(-£ 5.75-£ 16.39)\end{array}$ & $\begin{array}{c}£ 15.67 \\
(-£ 16.95-£ 48.29)\end{array}$ \\
\hline $\begin{array}{l}2010 / \\
2011\end{array}$ & 518 & $\begin{array}{c}£ 6.75 \\
(-£ 24.74-£ 38.24)\end{array}$ & $\begin{array}{c}£ 3.19 \\
(-£ 11.69-£ 18.08)\end{array}$ & $\begin{array}{c}£ 2.52 \\
(-£ 9.23-£ 14.27)\end{array}$ & $\begin{array}{c}£ 7.42 \\
(-£ 27.20-£ 42.05)\end{array}$ \\
\hline $\begin{array}{l}2011 / \\
2012\end{array}$ & 1,567 & $\begin{array}{c}£ 20.41 \\
(-£ 13.06-£ 53.88)\end{array}$ & $\begin{array}{c}£ 9.65 \\
(-£ 6.17-£ 25.47)\end{array}$ & $\begin{array}{c}£ 7.62 \\
(-£ 4.87-£ 20.10)\end{array}$ & $\begin{array}{c}£ 22.42 \\
(-£ 14.36-£ 59.24)\end{array}$ \\
\hline $\begin{array}{l}2012 / \\
2013\end{array}$ & 2,752 & $\begin{array}{c}£ 35.84 \\
(£ 0.26-£ 71.42)\end{array}$ & $\begin{array}{c}£ 16.94 \\
(£ 0.12-£ 33.76)\end{array}$ & $\begin{array}{c}£ 13.37 \\
(£ 0.01-£ 26.65)\end{array}$ & $\begin{array}{c}£ 39.41 \\
(£ 0.29-£ 78.53)\end{array}$ \\
\hline $\begin{array}{l}2013 / \\
2014\end{array}$ & 4,475 & $\begin{array}{c}£ 58.28 \\
(£ 20.48-£ 96.08)\end{array}$ & $\begin{array}{c}£ 27.55 \\
(£ 9.68-£ 45.42)\end{array}$ & $\begin{array}{c}£ 21.75 \\
(£ 7.64-£ 35.85)\end{array}$ & $\begin{array}{c}£ 64.08 \\
(£ 22.52-£ 105.64)\end{array}$ \\
\hline $\begin{array}{l}2014 / \\
2015\end{array}$ & 8,224 & $\begin{array}{c}£ 107.11 \\
(£ 67.00-£ 147.22)\end{array}$ & $\begin{array}{c}£ 50.63 \\
(£ 31.67-£ 69.59)\end{array}$ & $\begin{array}{c}£ 39.97 \\
(£ 25.00-£ 54.93)\end{array}$ & $\begin{array}{c}£ 117.77 \\
(£ 73.67-£ 161.87)\end{array}$ \\
\hline $\begin{array}{l}2015 / \\
2016\end{array}$ & 12,599 & $\begin{array}{c}£ 164.10 \\
(£ 121.60-£ 206.60)\end{array}$ & $\begin{array}{c}£ 77.57 \\
(£ 57.48-£ 97.65)\end{array}$ & $\begin{array}{c}£ 61.23 \\
(£ 45.38-£ 77.09)\end{array}$ & $\begin{array}{c}£ 180.44 \\
(£ 133.71-£ 227.16)\end{array}$ \\
\hline Total & 31,099 & $\begin{array}{c}£ 405.05 \\
(£ 171.55-£ 613.44)\end{array}$ & $\begin{array}{c}£ 191.46 \\
(£ 59.75-£ 323.17)\end{array}$ & $\begin{array}{c}£ 146.46 \\
(£ 64.02-£ 228.90)\end{array}$ & $\begin{array}{c}£ 445.37 \\
(£ 138.99-£ 751.75)\end{array}$ \\
\hline
\end{tabular}

*In the year 2008/2009, the total number of involuntary admissions was lower than predicted

Table 3: Predicted cost savings for two alternatives to account for excess involuntary admissions 


\subsection{Regression Models for Involuntary Admissions and Place of Safety Detentions}

In the final stage of analysis, stepwise linear regression was performed to identify potential predictors of admissions using all available financial years (1999/2000 to 2015/16). The results of five regression models are reported in Tables 4 and 5. When comparing between models, we took into account estimation errors (Root Mean Squared Error; RMSE), model fit (Adjusted R2) and prediction precision (PI Range). Then, we explored whether any variable had a significant independent relationship with the observed trend.

We considered Model 5 to be the best predictive model for involuntary admissions (also see Appendix B). We included homelessness rates, police staffing and bed availability (mental health, general and acute, learning disability and maternity) as covariates in this model. None of these variables made a significant contribution for predicting involuntary admissions. Homelessness rates made a significant contribution to Model 4 ( $\mathrm{p}=.04)$. However, homelessness is unlikely to be a reliable independent predictor, as the correlation was small $(\beta=.15)$ and the model was neither precise nor fit the data well. No other variable made a significant contribution across models. Therefore, we are unable to conclude that any of these variables made a substantial contribution to the observed trend in involuntary admissions.

We considered Model 2 to be the best predictive model for Place of Safety detentions. We included only mental health bed availability as a covariate in this model, which made a significant independent contribution for predicting Place of Safety detentions $(\mathrm{p}=.04)$. This suggests that lower bed availability may partly explain the increased rates of Place of Safety detentions between 2008 and 2016. However, even when using Model 2 to generate predictions, observed involuntary admissions and Place of Safety detentions are still substantially higher than the predicted range after 2008 (see Appendix B). No other variable was a significant predictor of Place of Safety detentions across models.

\begin{tabular}{|c|c|c|c|c|c|c|c|c|c|c|}
\hline \multirow[t]{2}{*}{ Variable } & \multicolumn{2}{|c|}{ Model 1} & \multicolumn{2}{|c|}{ Model 2} & \multicolumn{2}{|c|}{ Model 3} & \multicolumn{2}{|c|}{ Model 4} & \multicolumn{2}{|c|}{ Model 5} \\
\hline & $\beta$ & $p$ & $\beta$ & $p$ & $\beta$ & $p$ & $\beta$ & $p$ & $\beta$ & $p$ \\
\hline Year & 164.18 & .10 & -345.39 & .28 & 14.32 & .96 & 936.56 & .18 & 2281.91 & .11 \\
\hline MH beds & - & - & -.55 & .12 & .16 & .71 & .47 & .28 & 1.75 & .12 \\
\hline Homelessness & - & - & - & - & -.15 & .08 & -.15 & $.04 *$ & -.02 & .06 \\
\hline Police staffing & - & - & - & - & - & - & -.09 & .15 & .11 & .11 \\
\hline G\&A beds & - & - & - & - & - & - & - & - & -.18 & .22 \\
\hline Maternity beds & - & - & - & - & - & - & - & - & 5.90 & .12 \\
\hline LD beds & - & - & - & - & - & - & - & - & -2.02 & .14 \\
\hline Adjusted R2 & \multicolumn{2}{|c|}{.24} & \multicolumn{2}{|c|}{.43} & \multicolumn{2}{|c|}{.76} & \multicolumn{2}{|c|}{.66} & \multicolumn{2}{|c|}{.98} \\
\hline Root MSE & \multicolumn{2}{|c|}{677.40} & \multicolumn{2}{|c|}{585.35} & \multicolumn{2}{|c|}{453.60} & \multicolumn{2}{|c|}{379.50} & \multicolumn{2}{|c|}{113.19} \\
\hline PI Range & \multicolumn{2}{|c|}{5348.49} & \multicolumn{2}{|c|}{4778.34} & \multicolumn{2}{|c|}{4973.19} & \multicolumn{2}{|c|}{9593.86} & \multicolumn{2}{|c|}{6758.20} \\
\hline
\end{tabular}

Table 4: Regression coefficients and covariates for each model predicting involuntary admissions. 


\begin{tabular}{|c|c|c|c|c|c|c|c|c|c|c|}
\hline \multirow[t]{2}{*}{ Variable } & \multicolumn{2}{|c|}{ Model 1} & \multicolumn{2}{|c|}{ Model 2} & \multicolumn{2}{|c|}{ Model 3} & \multicolumn{2}{|c|}{ Model 4} & \multicolumn{2}{|c|}{ Model 5} \\
\hline & $\beta$ & $p$ & $\beta$ & $p$ & $\beta$ & $p$ & $\beta$ & $p$ & $\beta$ & $p$ \\
\hline Year & 582.33 & $.00^{*}$ & 306.63 & .31 & 354.01 & .06 & 394.70 & .37 & 1010.39 & .47 \\
\hline MH beds & - & - & -.30 & $.04 *$ & -.21 & .36 & -.19 & .50 & .93 & .45 \\
\hline Homelessness & - & - & - & - & -.00 & .60 & -.00 & .60 & -.00 & .97 \\
\hline Police staffing & - & - & - & - & - & - & -.00 & .92 & .02 & .71 \\
\hline G\&A beds & - & - & - & - & - & - & - & - & -.25 & .35 \\
\hline Maternity beds & - & - & - & - & - & - & - & - & 2.99 & .46 \\
\hline LD beds & - & - & - & - & - & - & - & - & -1.11 & .48 \\
\hline Adjusted R2 & \multicolumn{2}{|c|}{.97} & \multicolumn{2}{|c|}{.98} & \multicolumn{2}{|c|}{.97} & \multicolumn{2}{|c|}{.98} & \multicolumn{2}{|c|}{.97} \\
\hline Root MSE & \multicolumn{2}{|c|}{301.16} & \multicolumn{2}{|c|}{222.26} & \multicolumn{2}{|c|}{263.49} & \multicolumn{2}{|c|}{236.04} & \multicolumn{2}{|c|}{268.63} \\
\hline 95\% PI Range & \multicolumn{2}{|c|}{2377.85} & \multicolumn{2}{|c|}{1814.36} & \multicolumn{2}{|c|}{2494.27} & \multicolumn{2}{|c|}{13818.15} & \multicolumn{2}{|c|}{15815.38} \\
\hline
\end{tabular}

Table 5: Regression coefficients and covariates for each model predicting Place of Safety detentions. 


\section{DISCUSSION}

\subsection{Interpretation of findings}

While there was a gradual increase in both involuntary admissions and Place of Safety detentions prior to 2008, marked increases can be seen in Place of Safety detentions from 2008/09 and in involuntary admissions from 2012/13. These rates were considerably higher than expected based on previous trends with the difference resulting in substantial additional costs to the NHS. Our results broadly support the findings of a recent CQC report (Care Quality Commission, 2018) that chronologically, there are likely several contributory factors. However, as these factors are complex to measure, we are unable to quantify the relative impact of each factor.

There has been a consistent year-on-year increase in admission rates since the end of the National Service Framework for Mental Health and the beginning of austerity measures in 2010/11. The trend has increased by a larger margin in each year since, rising substantially beyond the predicted range within two years. This may suggest a cumulative effect of austerity, building on the stagnant or reduced funding in many mental health services and trusts, (BMA, 2018; The Royal College of Psychiatrists, 2018) and across the voluntary and social care sectors (Iacobucci, 2018; Local Government Association, 2016; Rethink Mental Illness, 2011). A smaller but less definitive rise within the predicted range was seen immediately following the implementation of the Mental Health Act (2007) and the economic recession of 2007/08.

We found some evidence that reductions in mental health bed availability may explain some of the post2008 increases in involuntary admissions and Place of Safety detentions. A plausible explanation is that the MHA is being increasingly relied upon to secure a hospital bed (Glover-Thomas, 2018). For example, the CQC report proposed (Care Quality Commission, 2018) that changes in mental health service provision and bed management may have reduced the occurrence of voluntary admissions. However, even when accounting for this variable, the observed rates were still above the predicted range at the same points as the original analysis. This is likely because bed availability has decreased steadily throughout the reporting period. Therefore, we argue that reductions in bed availability may have worsened the impact of austerity measures (including reduced community investment) on these rates (Thornicroft, Deb, \& Henderson, 2016), but they did not cause the increases independently. We did not find evidence of homelessness, police staffing or other bed availability trends having independently contributed to post2008 rates for either variable. Rather, our predictions for involuntary admissions gradually improved as we included more variables that may have been affected by austerity. We consider specific impactful events below.

Following the Cheshire West ruling in 2014, there was an immediate peak in involuntary admissions. As DoLS saw a similar and parallel increase to this (see Figure 2)(NHS Digital, 2017), it is unlikely that increases in involuntary admissions were due to a preference for using the Mental Health Act at the expense of the Mental Capacity Act, in situations where both could potentially apply. Instead, part of this increase may have been the result of a greater number of patients being detained under section, who would previously have been admitted informally prior to the revised DoLS (Care Quality Commission, 2018). A reduced tendency to use informal admissions may be due to a general uncertainty about what legally constitutes a deprivation of liberty (Lennard, 2014) and concerns that an informal admission will be retrospectively judged as such (Law Commission, 2017). However, this is likely an insufficient explanation for the overall increase in involuntary admissions, as only a minority of DoLS applications 
relate to mental health (NHS Digital, 2017) and the initial increase in involuntary admissions predates the Cheshire West ruling.

While the substantial rise of Place of Safety detentions in 2008 coincides with the introduction of the 2007 amendments to the Mental Health Act (implemented in 2008), we argue that this is unlikely to be the primary cause because no changes were made to the Section 136 legislative criteria for detention (Zigmond, 2012), yet there were marked increases in Place of Safety detentions. Adjustments to accompanying professional guidance, may have changed how legislation was implemented during the study period, with practitioners being urged not to use police cells as Places of Safety, (Department of Health, 2017) but this is unlikely to have resulted in the increase in detentions that was seen. A more plausible explanation is socioeconomic deprivation, resulting from the 2008 recession, which has been shown to be associated with higher mental health need (J. Watkins et al., 2017). The absence of adequate support elsewhere has since been cited as a potential driver for more risk-averse policing (Thomas \& Forrester-Jones, 2018). Therefore, we suggest that the increase in Place of Safety detentions is more likely a result of increased demand in crisis presentations, as these may be more sensitive to the immediate effect of the economic recession and exacerbated in the long-term by prolonged reductions in healthcare and social spending.

There was a substantial decline in the total police workforce between $2008(144,353)$ and $2016(125,574)$, with a year on year decrease in frontline officers (Home Office, 2018). These changes alone did not significantly predict admission or detention rates, perhaps because our analyses did not include intermediary factors that could have worsened the impact of reduced police numbers. For example, the increased demand on the police in responding to mental health crises (College of Policing, 2015), shortfalls in the mental health workforce (NHS Improvement, 2019) and competition for resources (Horspool, Drabble, \& O'Cathain, 2016) could have worsened the impact of policing shortages at different timepoints. Increases in Place of Safety detentions from 2012/13 may also be partly explained by changes in police behaviour. First, recommendations extending the settings in which Section 136 could apply led to substantial reductions in the use of police cells to detain people with a mental health problem (Mouko, Goddard, \& Nimmo-Smith, 2015) (a 391\% decrease between 2011/12 and 2015/16; see Figure 3 ). Second, the introduction of street triage programmes may also have led to similar changes in police behaviour. While some areas piloted these, strict national regulations against the use of police cells for detentions were not in place until December 2017 (Department of Health, 2017) and the introduction of street triage appears to have led to a reduction in the use of Section 136 (Keown et al., 2016; Reveruzzi \& Pilling, 2016). Therefore, it is unlikely that these changes alone have led to the marked increase observed in hospital-based Place of Safety detentions (617\%). Further, this would not account for the earlier increases following the recession, which were substantially above the predicted range.

Irrespective of the reason for these rises, there are substantial costs associated with the increased use of the Mental Health Act. In the eight years since 2008/09, our analyses estimate that the NHS spent $£ 6.8$ billion on involuntary admissions and $£ 120$ million on Place of Safety detentions. These costs are considerably higher than expected based on trends before 2008/09: a further $£ 597$ million and $£ 46$ million excess was spent on involuntary admissions and Place of Safety detentions, respectively. Cost savings for involuntary admissions would be maintained if these people were offered alternative care, such as informal admission $(\sim £ 191$ million) or crisis resolution and home treatment teams $(\sim £ 445$ million$)$. 


\subsection{Limitations}

A number of individual, local and service-level factors, such as ethnicity, migration, socioeconomic status and the availability of acute beds, have been suggested by recent reviews (Bhui et al., 2003; Care Quality Commission, 2018; Weich et al., 2017) to have contributed to the recent rise in involuntary admissions. Our regression analysis was unable to address these factors directly, as national statistics were not available. It is possible that one or more of these could have contributed to the rising rates. Furthermore, while a large national data source was used to collect rates of involuntary admissions, there were some minor changes in data collection methodology over the study period. (NHS Digital, 2016)

Many of the costs outlined in this report are conservative estimates and are restricted to the mental health care budget, so do not take into account wider expenditure (for example, associated with the criminal justice system and ambulance trusts). Furthermore, our cost estimates do not account for forensic detentions, detentions made to independent sector facilities, and other activities such as mental health tribunals. However, these only account for a minority of all involuntary admissions. (NHS Digital, 2017)

\subsection{Implications and future directions}

Ideally involuntary detentions should be a rare occurrence and a last resort for people who are mentally very unwell. The rise in section 2 and 3 admissions suggests that there is a growing number of people experiencing high levels of distress who need to access services. As well as being costly, we argue that these trends are unwelcome given that involuntary admissions are associated with a range of negative outcomes for the person (Kallert, Glockner, \& Schutzwohl, 2008). These may include longer lengths of stay (Dimitri et al., 2018), increased stigma and discrimination (Xu et al., 2018), increased use of restraint, enforced medication and seclusion (Raboch et al., 2010), poor user experience and subsequent readmission on an involuntary basis (Kallert et al., 2008). The rise in Place of Safety detentions is also problematic, as the involvement of the police and the criminal justice system has been shown to negatively influence future help-seeking behaviour and reduce the uptake of mental health care, particularly for certain groups such as black men (Gajwani, Parsons, Birchwood, \& Singh, 2016; Henderson et al., 2015). Most of these people do not go on to receive a Section 2 or 3 detention (NHS Digital, 2017). This suggests that some of these Place of Safety detentions may have been avoided if more alternatives in the community were available.

The purpose of involuntary admissions and Place of Safety detentions is to prevent negative behavioural outcomes, particularly suicide, self-harm and harm to others. Although safety may be improved in the short term, there is mixed evidence regarding whether these measures are effective in the long term (Kallert et al., 2008; Shah, 2012) . Considering this, perhaps the most effective way to reduce negative behavioural outcomes is to prevent mental health crises, thus reducing the use of involuntary detention. Alternatives to involuntary admission that support therapeutic alliance and engagement in treatment, such as least-restrictive decision-making, must be encouraged. There is growing evidence, accompanied by a policy drive, that the development of more comprehensive crisis care pathways could replace some of the functions of traditional inpatient care (NHS England, 2019b). New proposed models of mental healthcare delivery strengthen the involvement of primary care (Mann et al., 2014), promote self-referrals, and improve the provision of community care, including complementary and alternative crisis services (such as crisis houses and Crisis Resolution and Home Treatment Teams). In addition, initiatives such as street triage could reduce Place of Safety detentions (Keown et al., 2016; Reveruzzi \& Pilling, 2016). To be effective such services need to be resourced adequately; this includes addressing existing shortfalls in the 
workforce (NHS Improvement, 2019) and using digital technology to augment existing care pathways (Health Education England, 2019).

This study suggests there is a growing need to better understand the complex relationship between austerity measures, legislation and guidance, and involuntary admissions. So far, comparative national and international studies have suggested some associations, but they seem to have lacked sufficient power to understand why these rates vary (de Stefano \& Ducci, 2008; Sheridan Rains et al., 2019). Therefore, closer inspection of the recent impact of austerity at the service level is urgently required. This should provide a better understanding of how changes in health service provision and wider social support have contributed to changes in the rate of crisis presentation and thereby impacted on involuntary admissions.

Further research is also needed to identify the specific populations over-represented in involuntary admissions and the social, cultural, resource and clinical practice issues which relate to their experiences. Finally, the Liberty Protection Safeguards, a pending reform of DoLS (Dyer, 2017) should be reviewed for its impact on involuntary admissions. Ideally, this would include detailed demographic data profiles (such as age and ethnicity) and the proportion of people with mental health problems who were subject to these measures.

\section{CONCLUSIONS}

Our findings suggest that specific impactful events may have contributed to the significant and prolonged rise in involuntary admissions and Place of Safety detentions, which have incurred substantial costs to the NHS. The economic recession and subsequent austerity measures are particularly likely to have contributed to these increases.

National initiatives, which ease current austerity measures and restore mental health funding, may play an important role in both reducing involuntary admissions and advancing mental health equality. As a consequence, this may lead to long-term substantial cost savings.

\section{ACKNOWLEDGEMENTS}

None.

\section{FUNDING}

This research did not receive any specific grant from funding agencies in the public, commercial, or not for profit sectors. SS is supported by the National Institute for Health Research (NIHR) Biomedical Research Centre at South London and Maudsley NHS Foundation Trust and King's College London and was part of the English Department of Health working group reviewing the Mental Health Act. SP is supported by the NIHR University College London Hospitals Biomedical Research Centre and is in receipt of funding from the National Institute for Clinical Excellence (NICE) and the Royal College of Psychiatrists. The views expressed are those of the author(s) and not necessarily those of the NHS, NICE, the NIHR or the Royal College of Psychiatrists.

\section{DECLARATIONS OF INTEREST}

None. 


\section{DATA STATEMENT}

All data utilised for the present study is publicly available. 


\section{REFERENCES}

Bhui, K., Stansfeld, S., Hull, S., Priebe, S., Mole, F., \& Feder, G. (2003). Ethnic variations in pathways to and use of specialist mental health services in the UK. Systematic review. Br J Psychiatry, 182, 105-116.

BMA. (2018). Lost in transit? Funding mental health services in England. . Retrieved from https://www.bma.org.uk/collective-voice/policy-and-research/public-and-populationhealth/mental-health/funding-mental-health-services

Care Quality Commission. (2018). Mental Health Act: The rise in the use of the MHA to detain people in England. Retrieved from https://www.cqc.org.uk/publications/themed-work/mentalhealth-act-rise-mha-detain-england

Centre for Mental Health. (2018). The future of the mental health workforce. Retrieved from https://www.centreformentalhealth.org.uk/sites/default/files/201809/CentreforMentalHealth Future mental health workforce.pdf

College of Policing. (2015). College of Policing analysis: Estimating demand on the police service. Retrieved from https://www.college.police.uk/News/Collegenews/Documents/Demand\%20Report\%2023 115 noBleed.pdf

Curtis L, B. A. (2017). Unit Costs of Health and Social Care 2017. Retrieved from https://www.pssru.ac.uk/project-pages/unit-costs/unit-costs-2017/

de Stefano, A., \& Ducci, G. (2008). Involuntary admission and compulsory treatment in Europe: an overview. International Journal of Mental Health, 37(3), 10-21.

Department for Constitutional Affairs. (2016). Mental Capacity Act 2005 Code of Practice. Retrieved from https://www.gov.uk/government/publications/mental-capacity-act-code-of-practice

Department of Health. (2009). The Bradley Report. Retrieved from https://lx.iriss.org.uk/sites/default/files/resources/The\%20Bradley\%20report.pdf

Department of Health. (2014). Mental Health Crisis Care Concordat: Improving outcomes for people experiencing mental health crisis. Retrieved from https://www.crisiscareconcordat.org.uk/wpcontent/uploads/2014/04/36353 Mental Health Crisis accessible.pdf

Department of Health. (2015). Mental Health Act 1983: Code of Practice Retrieved from https://assets.publishing.service.gov.uk/government/uploads/system/uploads/attachment data/file/435512/MHA Code of Practice.PDF

Department of Health. (2017). Guidance for the implementation of changes to police powers and places of safety provisions in the mental health act 1983. Retrieved from https://assets.publishing.service.gov.uk/government/uploads/system/uploads/attachment data/file/656025/Guidance on Police Powers.PDF

DHSC. (1999). A National Service Framework for Mental Health. Retrieved from https://www.gov.uk/government/publications/quality-standards-for-mental-health-services

DHSC. (2018a). Independent Review of the Mental Health Act. Retrieved from https://www.gov.uk/government/groups/independent-review-of-the-mental-health-act

DHSC. (2018b). Independent Review of the Mental Health Act: interim report. Retrieved from https://www.gov.uk/government/groups/independent-review-of-the-mental-health-act

Dimitri, G., Giacco, D., Bauer, M., Bird, V. J., Greenberg, L., Lasalvia, A., . . Priebe, S. (2018). Predictors of length of stay in psychiatric inpatient units: Does their effect vary across countries? Eur Psychiatry, 48, 6-12. doi:10.1016/j.eurpsy.2017.11.001

Docherty, M., \& Thornicroft, G. (2015). Specialist mental health services in England in 2014: overview of funding, access and levels of care. Int J Ment Health Syst, 9, 34. doi:10.1186/s13033-015-0023-9

Dyer, C. (2017). New safeguards are urgently needed for people with reduced capacity, report says. $B M J, 356$, j1336. doi:10.1136/bmj.j1336 
Gajwani, R., Parsons, H., Birchwood, M., \& Singh, S. P. (2016). Ethnicity and detention: are Black and minority ethnic (BME) groups disproportionately detained under the Mental Health Act 2007? Social psychiatry and psychiatric epidemiology, 51(5), 703-711.

Glover-Thomas, N. (2018). Decision-Making Behaviour under the Mental Health Act 1983 and Its Impact on Mental Health Tribunals: An English Perspective. Laws, 7(2), 12.

Health Education England. (2019). Preparing the healthcare workforce to deliver the digital future. Retrieved from https://topol.hee.nhs.uk/wp-content/uploads/HEE-Topol-Review-2019printable.pdf

Henderson, R., Williams, P., Gabbidon, J., Farrelly, S., Schauman, O., Hatch, S., ... Group, M. S. (2015). Mistrust of mental health services: ethnicity, hospital admission and unfair treatment. Epidemiology and Psychiatric Sciences, 24(3), 258-265.

Home Office. (2015). Alternative place of safety: West Sussex pilot evaluation 2015. Retrieved from https://www.gov.uk/government/publications/alternative-place-of-safety-west-sussex-pilotevaluation-2015

Home Office. (2018). Police Workforce, England and Wales, 31 March 2018. Retrieved from https://assets.publishing.service.gov.uk/government/uploads/system/uploads/attachment data/file/726401/hosb1118-police-workforce.pdf

Horspool, K., Drabble, S. J., \& O'Cathain, A. (2016). Implementing street triage: a qualitative study of collaboration between police and mental health services. BMC Psychiatry, 16(1), 313.

HSCIC. (2016). Online Omnibus KP9O collection. Retrieved from https://www.gov.uk/government/statistics/inpatients-formally-detained-in-hospitals-underthe-mental-health-act-1983-and-patients-subject-to-supervised-community-treatment2015-16

lacobucci, G. (2018). Budget cuts force local councils into "narrow" focus on social care, warns watchdog. BMJ, 360, k1113. doi:10.1136/bmj.k1113

Independent Mental Health Taskforce. (2016). The Five Year Forward View for Mental Health. Retrieved from https://www.england.nhs.uk/mental-health/taskforce/

Johnson, S. (2013). Can we reverse the rising tide of compulsory admissions? Lancet, 381(9878), 1603-1604. doi:10.1016/S0140-6736(13)60442-0

Jones, R. M. (2005). Mental Capacity Act Manual London: Sweet \& Maxwell.

Kallert, T. W., Glockner, M., \& Schutzwohl, M. (2008). Involuntary vs. voluntary hospital admission. A systematic literature review on outcome diversity. Eur Arch Psychiatry Clin Neurosci, 258(4), 195-209. doi:10.1007/s00406-007-0777-4

Keown, P., French, J., Gibson, G., Newton, E., Cull, S., Brown, P., . . McKinnon, I. (2016). Too much detention? Street Triage and detentions under Section 136 Mental Health Act in the NorthEast of England: a descriptive study of the effects of a Street Triage intervention. BMJ Open, 6(11), e011837. doi:10.1136/bmjopen-2016-011837

Keown, P., Weich, S., Bhui, K. S., \& Scott, J. (2011). Association between provision of mental illness beds and rate of involuntary admissions in the NHS in England 1988-2008: ecological study. $B M J, 343$, d3736. doi:10.1136/bmj.d3736

Law Commission. (2017). Mental Capacity and Deprivation of Liberty Summary. Retrieved from https://www.lawcom.gov.uk/project/mental-capacity-and-deprivation-of-liberty/

Lebenbaum, M., Chiu, M., Vigod, S., \& Kurdyak, P. (2018). Prevalence and predictors of involuntary psychiatric hospital admissions in Ontario, Canada: a population-based linked administrative database study. BJPsych Open, 4(2), 31-38. doi:10.1192/bjo.2017.4

Ledolter, J. (2013). Data mining and business analytics with R. New York: Wiley

Lennard, C. (2014). Deprivation of Liberty Safeguards: complexity, confusion and case law - a commentary. Social Care and Neurodisability, 5(4), 245-255.

doi:https://doi.org/10.1108/SCN-11-2013-0040

Local Government Association. (2016). Adult social care funding: 2016 state of the nation report. Retrieved from London: 
Mann, F., Fisher, H. L., Major, B., Lawrence, J., Tapfumaneyi, A., Joyce, J., . . Johnson, S. (2014). Ethnic variations in compulsory detention and hospital admission for psychosis across four UK Early Intervention Services. BMC Psychiatry, 14(1), 256. doi:10.1186/s12888-014-0256-1

Mattheys, K. (2015). The coalition, austerity and mental health Disability and Society, 30(3), 475-478. doi:10.1080/09687599.2014.1000513

Mouko, J., Goddard, A., \& Nimmo-Smith, V. (2015). How safe is our "place of safety"? Clinical guidance promoting safer medical care of patients detained under section 136 of the Mental Health Act. BMJ Qual Improv Rep, 4(1). doi:10.1136/bmjquality.u209141.w3721

New Horizons. (2009). Towards a shared vision for mental health. Retrieved from https://www.choiceforum.org/docs/sharedvis.pdf

NHS Digital. (2016). Mental health bulletin: 2015-16 annual report. Retrieved from https://digital.nhs.uk/data-and-information/publications/statistical/mental-healthbulletin/mental-health-bulletin-2015-16-annual-report

NHS Digital. (2017). Deprivation of Liberty Safeguards (England) Annual Report 2016-17: Annex ADemographic Data Tables. Retrieved from https://digital.nhs.uk/data-andinformation/publications/statistical/mental-capacity-act-2005-deprivation-of-libertysafeguards-assessments/mental-capacity-act-2005-deprivation-of-liberty-safeguardsengland-2016-17-official-statistics

NHS Digital. (2019). NHS Workforce Statistics - November 2018. Retrieved from https://digital.nhs.uk/data-and-information/publications/statistical/nhs-workforcestatistics/november-2018

NHS England (Producer). (2019a). Bed Availability and Occupancy Data - Overnight. Retrieved from https://www.england.nhs.uk/statistics/statistical-work-areas/bed-availability-andoccupancy/bed-data-overnight/

NHS England. (2019b). The NHS Long Term Plan. Retrieved from https://www.longtermplan.nhs.uk/publication/nhs-long-term-plan/

NHS Improvement. (2019). Interim NHS People Plan. Retrieved from https://improvement.nhs.uk/resources/interim-nhs-people-plan/

Office for National Statistics. (2015). Expenditure on Healthcare in the UK: 2013. Retrieved from https://www.ons.gov.uk/peoplepopulationandcommunity/healthandsocialcare/healthcares ystem/articles/expenditureonhealthcareintheuk/2015-03-26.

Office for National Statistics. (2017a). Police workforce, England and Wales, 31 March 2016. Retrieved from https://www.gov.uk/government/statistics/police-workforce-england-andwales-31-march-2016

Office for National Statistics. (2017b). Statutory homelessness and homelessness prevention and relief, England: January to March 2017. Retrieved from https://www.gov.uk/government/statistics/statutory-homelessness-and-homelessnessprevention-and-relief-england-january-to-march-2017

Penny, C., \& Exworthy, T. (2015). A gilded cage is still a cage: Cheshire West widens 'deprivation of liberty'. The British Journal of Psychiatry, 206(2), 91-92.

Raboch, J., Kalisova, L., Nawka, A., Kitzlerova, E., Onchev, G., Karastergiou, A., . . Kallert, T. W. (2010). Use of coercive measures during involuntary hospitalization: findings from ten European countries. Psychiatr Serv, 61(10), 1012-1017. doi:10.1176/ps.2010.61.10.1012

Rethink Mental Illness. (2011). The Mental Health Strategy, system reforms and spending pressures: what do we know so far? Retrieved from

https://www.mentalhealth.org.uk/sites/default/files/mental health strategy what do we know so far.pdf

Reveruzzi, B., \& Pilling, S. (2016). Street triage report on the evaluation of nine pilot schemes in England. Retrieved from https://www.ucl.ac.uk/pals/sites/pals/files/street triage evaluation final report.pdf 
Shah, A. (2012). The relationship between the use of Mental Health Act and general population suicide rates in England and Wales. J Inj Violence Res, 4(1), 26-29. doi:10.5249/jivr.v4i1.66

Sheridan Rains, L., Zenina, T., Dias, M. C., Jones, R., Jeffreys, S., Branthonne-Foster, S., . . Johnson, S. (2019). Variations in patterns of involuntary hospitalisation and in legal frameworks: an international comparative study. Lancet Psychiatry, 6(5), 403-417. doi:10.1016/S22150366(19)30090-2

StrataCorp. (2017). Stata Statistical Software: Release 15 Retrieved from College Station, TX:

Szmukler, G., \& Weich, S. (2017). Has the Mental Health Act had its day? BMJ, 359, j5248. doi:10.1136/bmj.j5248

The King's Fund. (2015). Case Study 2: The National Service Framework for Mental Health in England. Retrieved from https://www.kingsfund.org.uk/publications/making-changepossible/national-service-framework-mental-health-england

The Royal College of Psychiatrists. (2018). Mental health trusts' income lower than in 2011-12. Retrieved from https://www.rcpsych.ac.uk/mediacentre/pressreleases2018/mentalhealthtrustincome.aspx

Thomas, A., \& Forrester-Jones, R. (2018). Understanding the changing patterns of behaviour leading to increased detentions by the Police under Section 136 of the Mental Health Act 1983. Policing: A Journal of Policy and Practice, 13(2), 134-146. doi:https://doi.org/10.1093/police/pay011

Thornicroft, G., Deb, T., \& Henderson, C. (2016). Community mental health care worldwide: current status and further developments. World Psychiatry, 15(3), 276-286.

Turnpenny, A., Petri, G., Finn, A., Beadle-Brown, J., \& Nyman, M. (2018). Mapping and understanding exclusion: institutional, coercive and community-based services and practices across Europe. Retrieved from https://mhe-sme.org/wpcontent/uploads/2018/01/Mapping-and-Understanding-Exclusion-in-Europe.pdf

Watkins, J., Wulaningsih, W., Da Zhou, C., Marshall, D. C., Sylianteng, G. D. C., Dela Rosa, P. G., .. . Maruthappu, M. (2017). Effects of health and social care spending constraints on mortality in England: a time trend analysis. BMJ Open, 7(11), e017722. doi:10.1136/bmjopen-2017017722

Watkins, S. (2017). Benchmarking Mental Health Services UK Results 2017. Paper presented the Benchmarking \& Good Practice in Mental Health Services Conference London

Weich, S., McBride, O., Twigg, L., Duncan, C., Keown, P., Crepaz-Keay, D., ... Bhui, K. (2017). Variation in compulsory psychiatric inpatient admission in England: a cross-classified, multilevel analysis. Lancet Psychiatry, 4(8), 619-626. doi:10.1016/S2215-0366(17)30207-9

Xu, Z., Lay, B., Oexle, N., Drack, T., Bleiker, M., Lengler, S., ... Rusch, N. (2018). Involuntary psychiatric hospitalisation, stigma stress and recovery: a 2-year study. Epidemiol Psychiatr Sci, 1-8. doi:10.1017/S2045796018000021

Zigmond, T. (2012). A Clinician's Brief Guide to the Mental Health Act (2017/03/11 ed.): RCPsych Publications

\section{AUTHOR DETAILS}

Corresponding author: Shubulade Smith (email: Shubulade.smith@kcl.ac.uk)

Shubulade Smith, MD1,2,3 [co]; Rebecca Gate, MSc3; Kevin Ariyo, MSc3,4; Rob Saunders, PhD4; Clare Taylor, PhD3; Kamaldeep Bhui, MD5; Ifigeneia Mavranezouli, PhD4; Margaret Heslin, PhD1; Helen Greenwood, MSc3; Hannah Matthews, PhD4; Phoebe Barnett, MSc4; Stephen Pilling, $\mathrm{PhD} 3,4,6$

1 Department of Forensic and Neurodevelopmental Science, Institute of Psychiatry, Psychology and Neuroscience, Kings College London, De Crespigny Park, London SE5 8AF 
2 South London and Maudsley NHS Foundation Trust, Maudsley Hospital, Denmark Hill, Camberwell, London SE5 8AZ

3 National Collaborating Centre for Mental Health, Royal College of Psychiatrists, 21 Prescot Street, London, E1 8BB

4 Centre for Outcomes Research and Effectiveness, Department of Clinical Educational and Health Psychology, University College London, 1-19 Torrington Place, London, WC1E 7HB

5 Centre for Psychiatry, Wolfson Institute of Preventative Medicine, Barts and the London School of Medicine and Dentistry, Queen Mary University of London, Charterhouse Square, London, EC1M 6BQ

6 Camden \& Islington NHS Foundation Trust, 4 St Pancras Way, London, NW1 OPE

\section{AUTHOR CONTRIBUTIONS}

SS, RG and SP: substantial contributions to the conception and design of the work and drafting of the document, including data collection and analysis, and interpretation of the data. SS and SP: responsible for critical revisions. KA: substantial contributions to design, data collection, analysis, interpretation and drafting of the document and processing revisions. RS: substantial contributions to data analysis. CT: substantial contributions to the drafting of the document and critical revisions. MH and IM: substantial contributions to interpretation of the data and data analysis (economic perspective). KB: substantial contributions to the interpretation of the data and critical revisions. HM: contributions to data collection, data analysis and drafting. HG and PB: critical revisions. All authors fully meet the ICMJE criteria for authorship. All have approved the final version of the work to be published and agree to be accountable for all aspects of the work in ensuring that questions related to the accuracy or integrity of any part of the work are appropriately investigated and resolved.

\section{RELEVANCE STATEMENT}

This is the first study, to our knowledge that explores the effect of the recession, legislation and subsequent austerity measures on the rates of involuntary admissions or Place of Safety detentions. Given the recent recommendations from the 2018 Mental Health Act review and the promise of increased funding for mental healthcare from the NHS Long-term Plan, it is both timely and crucial that policymakers, healthcare professionals, people using services and their carers are better informed of the factors (legislative and non-legislative) that may have led to these increases. These findings will support a more cost-effective approach to mental healthcare delivery.

\section{APPENDIX A: SUPPLEMENTARY TABLES}

\begin{tabular}{|c|c|c|c|c|}
\hline Item & Unit & $\begin{array}{l}\text { Individual unit cost (per } \\
\text { hour or day) }\end{array}$ & $\begin{array}{l}\text { Total estimated unit } \\
\text { cost }(2016 / 17)\end{array}$ & Assumptions \\
\hline Mental Health Act assessment & Per occurrence & $\begin{array}{l}\text { Consultant Psychiatrist } \\
(£ 108 / \mathrm{h}) \text {; AMHP }(£ 55 / \mathrm{h}) \text {; } \\
\text { Health care practitioner } \\
\text { (£53/h) }\end{array}$ & $£ 866$ & $\begin{array}{c}\text { Based on the assumption of } 3 \text { hours for two section } 12 \\
\text { doctors and an approved mental health professional and } \\
1 \text { hour of band } 7 \text { hospital-based practitioner triage. } \\
\text { (Source } 1,2,3) .\end{array}$ \\
\hline Crisis assessment & Per occurrence & $\begin{array}{l}\text { Consultant Psychiatrist } \\
(£ 108 / \mathrm{h}) ; \text { AMHP }(£ 55 / \mathrm{h}) ;\end{array}$ & $£ 489$ & $\begin{array}{c}\text { Based on the assumption of } 3 \text { hours for one section } 12 \\
\text { doctor and three hours for a band } 7 \text { approved mental } \\
\text { health professional. (Source } 1,2 \text { ). }\end{array}$ \\
\hline
\end{tabular}




\begin{tabular}{|c|c|c|c|c|}
\hline $\begin{array}{l}\text { Health-based Place of Safety } \\
\text { detention } \\
\text { (with conversion to Section } 2 \text { or } \\
\text { 3) }\end{array}$ & Per occurrence & Section 136 Suite $(£ 407 / d)$ & $£ 1,273$ & $\begin{array}{l}\text { Costed as an acute psychiatric ward for one bed day } \\
\text { plus one Mental Health Act assessment. (Source 4). }\end{array}$ \\
\hline $\begin{array}{l}\text { Health-based Place of Safety } \\
\text { detention (without conversion to } \\
\text { Section } 2 \text { or } 3 \text { ) }\end{array}$ & Per occurrence & Section 136 Suite ( $£ 407 / d)$ & $£ 896$ & $\begin{array}{l}\text { Costed as an acute psychiatric ward for one bed day } \\
\text { plus one crisis assessment. (Source } 4 \text { ). }\end{array}$ \\
\hline $\begin{array}{l}\text { Involuntary admission (under } \\
\text { Part II of the Mental Health Act } \\
\text { using either a Section } 2 \text { or } \\
\text { Section } 3 \text { order) }\end{array}$ & Per admission & $\begin{array}{l}\text { Acute psychiatric bed } \\
\qquad(£ 407 / \mathrm{d})\end{array}$ & $£ 18,315$ & $\begin{array}{l}\text { Based on the unit cost per acute psychiatric care bed } \\
\text { day multiplied by the average number of days per } \\
\text { admission (excluding leave) of patients detained under } \\
\text { the Mental Health Act at the point of admission to an } \\
\text { adult acute bed: } 45 \text { days. (Sources } 4 \& 5 \text { ). }\end{array}$ \\
\hline Voluntary admission & Per admission & $\begin{array}{l}\text { Acute psychiatric bed } \\
\qquad(£ 407 / d)\end{array}$ & $£ 12,535$ & $\begin{array}{l}\text { Based on the unit cost per acute psychiatric care bed } \\
\text { day multiplied by the average number of days per } \\
\text { admission (excluding leave) at the point of admission to } \\
\text { an adult acute bed: } 30.8 \text { days. (Sources } 4 \& 5 \text { ). }\end{array}$ \\
\hline $\begin{array}{l}\text { Crisis resolution and home } \\
\text { treatment }\end{array}$ & Per occurrence & Home treatment (£180/d) & $£ 4322$ & $\begin{array}{l}\text { Based on the average cost of home treatment per } \\
\text { contact in 2012/13. Inflated to } 2016 / 17 \text { figures using the } \\
\text { hospital and community services index. Then multiplied } \\
\text { by the average length of stay with a crisis team: } 27 \\
\text { days. (Sources } 6,7 \& 8 \text { ). }\end{array}$ \\
\hline
\end{tabular}

\section{Sources:}

1. 'Hospital-based health care staff', Curtis, L and Burns, A. Unit Costs of Health and Social Care 2017. Personal Social Services Research Unit, University of Kent, 2017. Available at http://www.pssru.ac.uk/project-pages/unit-costs/unit-costs-2017/.

2. 'Community-based social care staff', Curtis, L and Burns, A. Unit Costs of Health and Social Care 2016. Personal Social Services Research Unit, University of Kent, 2016. Available at http://www.pssru.ac.uk/project-pages/unit-costs/unit-costs-2016/.

3. 'Hospital-based health care staff', Curtis, L and Burns, A. Unit Costs of Health and Social Care 2016. Personal Social Services Research Unit, University of Kent, 2016. Available at http://www.pssru.ac.uk/project-pages/unit-costs/unit-costs-2016/.

4. 'Services for people with mental health problems', Curtis, L and Burns, A. Unit Costs of Health and Social Care 2017. Personal Social Services Research Unit, University of Kent, 2017. Available at http://www.pssru.ac.uk/project-pages/unit-costs/unit-costs-2017/.

5. NHS Benchmarking figures (see main text references). Also available at https://www.swlstg.nhs.uk/documents/related-documents/health-professionals/579-slpbenchmarking-slides/file

6. 'Health and social care teams', Curtis, L and Burns, A. Unit Costs of Health and Social Care 2016. Personal Social Services Research Unit, University of Kent, 2017. Available at https://www.pssru.ac.uk/project-pages/unit-costs/unit-costs-2016/

7. NHS Benchmarking Network: Mental Health Crisis Pathway Analysis. Retrieved from: https://www.crisiscareconcordat.org.uk/wp-content/uploads/2014/05/NHSBNMH-Crisis-Pathway-Analysis-28-2-2014-1.pdf

8. 'Inflation Indices', Curtis, L and Burns, A. Unit Costs of Health and Social Care 2017. Personal Social Services Research Unit, University of Kent, 2017. Available at http://www.pssru.ac.uk/project-pages/unitcosts/unit-costs-2017/

\section{Table A.1: Unit costs and assumptions for the costing model}




\begin{tabular}{|c|c|}
\hline Term & Definition \\
\hline $\begin{array}{l}\text { Beginning of the National } \\
\text { Service Framework }\end{array}$ & $\begin{array}{l}\text { The National Service Framework for Mental Health was a policy document that applied to all major mental health services for working age adults in England. This set ambitious } \\
\text { quality standards and outlined how they should be developed and measured over a 10-year period. Prior to this, the pattern of mental health services was largely determined by } \\
\text { local planners. (Docherty \& Thornicroft, 2015) It was published in September } 1999 \text { and implemented the following year. }\end{array}$ \\
\hline Mental Capacity Act (2005) & $\begin{array}{l}\text { Legislation introduced in } 2005 \text { that applies to all people aged } 16 \text { or over, in England and Wales, who may lack capacity to make decisions about their care and treatment. This } \\
\text { includes a framework to support people in their own decision making and care planning, or to support others to make decisions in the person's best interests. }\end{array}$ \\
\hline Mental Health Act (2007) & $\begin{array}{l}2007 \text { amendments to the Mental Health Act 1983, which applies to people with a 'mental health disorder' in England and Wales. This included a simplified definition of mental } \\
\text { disorder, a new provision to allow supervised community treatment, and a new tribunal structure. }\end{array}$ \\
\hline $\begin{array}{l}\text { Mental Health Act } \\
\text { amendment }(2007) \\
\text { implementation and } \\
\text { economic recession }\end{array}$ & The global financial crisis of 2008 and the implementation of the Mental Health Act in November 2008. \\
\hline DoLS & $\begin{array}{l}\text { Deprivation of Liberty Safeguards. An amendment to the Mental Capacity Act (2005) that protects the rights of people who cannot consent to their care arrangements in a care } \\
\text { home or hospital. It applies to people who are, or may be, judged to be deprived of their liberty in these settings. (Law Commission, 2017) }\end{array}$ \\
\hline $\begin{array}{l}\text { End of the National Service } \\
\text { Framework; } \\
\text { Beginning of austerity } \\
\text { measures. }\end{array}$ & $\begin{array}{l}\text { Austerity refers to widespread reforms in the UK, which reduced or stalled social spending (across healthcare and other areas) in response to the global financial crisis. In } \\
\text { England, this coincided with a new strategy for mental health services, including the discontinuation of the National Service Framework for Mental Health. This has since been } \\
\text { replaced by various policy documents, such as New Horizons (New Horizons, 2009) and the Five Year Forward View for Mental Health. (Independent Mental Health Taskforce, } \\
\text { 2016) }\end{array}$ \\
\hline First Street Triage pilot & $\begin{array}{l}\text { Street triage is a department of health-funded pilot scheme. (Reveruzzi \& Pilling, 2016) Beginning in 2013, this was managed by nine police forces, in partnership with local } \\
\text { NHS trusts. Where piloted, mental health professionals provided immediate advice to police officers when they came into contact with people who may be experiencing mental } \\
\text { health distress. }\end{array}$ \\
\hline Cheshire West & $\begin{array}{l}\text { A } 2014 \text { court ruling for the case P vs. Cheshire West and Chester Council and P \& Q v Surrey County Council. This widened the criteria of what can be considered a deprivation } \\
\text { of liberty to include when a person is under continuous supervision, is not free to leave, or lacks capacity to consent to arrangements (Penny \& Exworthy, 2015). In effect, this } \\
\text { resulted in more people being eligible for Deprivation of Liberty Safeguards. }\end{array}$ \\
\hline $\begin{array}{l}\text { First 'Alternative Place of } \\
\text { Safety' pilot }\end{array}$ & $\begin{array}{l}\text { The Department of Health sanctioned schemes in some areas to reduce the number of people detained in police custody following Section } 136 \text {. The first pilot took place in West } \\
\text { Sussex from March 2015,(Home Office, 2015) in parallel with the introduction of street triage in that area. }\end{array}$ \\
\hline
\end{tabular}

Table A.2: Definitions of each impacting event included in Figure 1. 


\begin{tabular}{|c|c|c|c|}
\hline \multirow[t]{2}{*}{ Year } & \multicolumn{2}{|c|}{ Health-based Place of Safety detentions } & \multirow{2}{*}{$\begin{array}{c}\text { Police-based Place of Safety detentions } \\
\text { Observed Rate }\end{array}$} \\
\hline & Observed rate & $\begin{array}{l}\text { Conversion rate to Section } 136 \\
\text { (\% total) }\end{array}$ & \\
\hline $2008 / 2009$ & 8,759 & $20 \%$ & $*$ \\
\hline $2009 / 2010$ & 12,300 & $16 \%$ & $*$ \\
\hline $2010 / 2011$ & 14,399 & $17 \%$ & $*$ \\
\hline $2011 / 2012$ & 15,240 & $17 \%$ & 8,667 \\
\hline $2012 / 2013$ & 14,296 & $17 \%$ & 7,761 \\
\hline $2013 / 2014$ & 17,315 & $17 \%$ & 6,028 \\
\hline $2014 / 2015$ & 19,718 & $16 \%$ & 3,996 \\
\hline $2015 / 2016$ & 23,521 & $17 \%$ & 1,764 \\
\hline
\end{tabular}

Table A.3: Observed and predicted number of Place of Safety (PoS) detentions in England 2010/2011 to 2015/2016

*Data for Police-based Places of Safety were only available from the year 2011/2012.

Figures were obtained from NHS Benchmarking (see main text references) 


\section{APPENDIX B: SUPPLEMENTARY Figures}

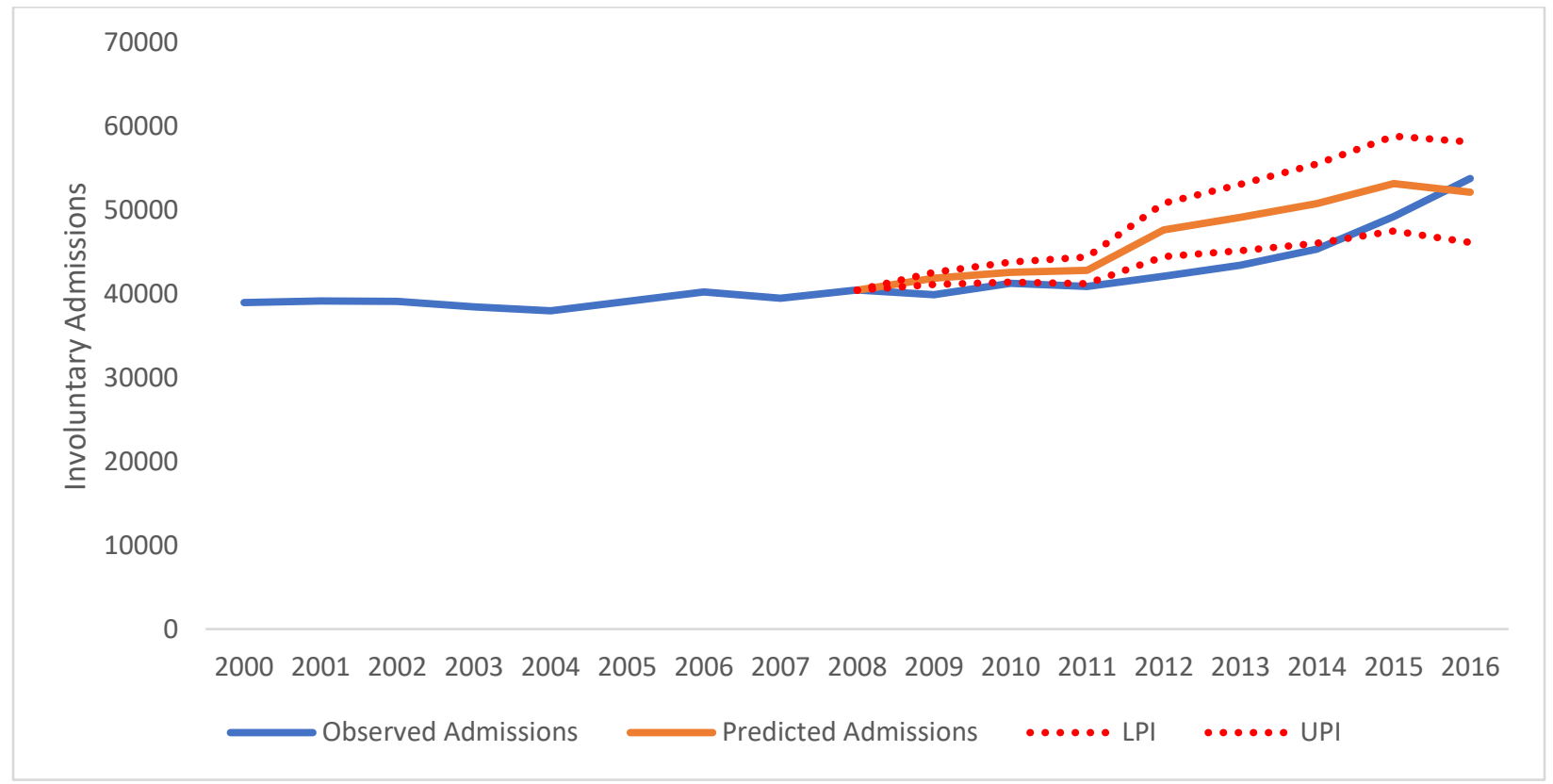

Figure B1: Observed involuntary admissions in England between 1999/00 to 2015/2016, and predicted rates, adjusted for mental health bed availability between 1999/00 and 2015/16

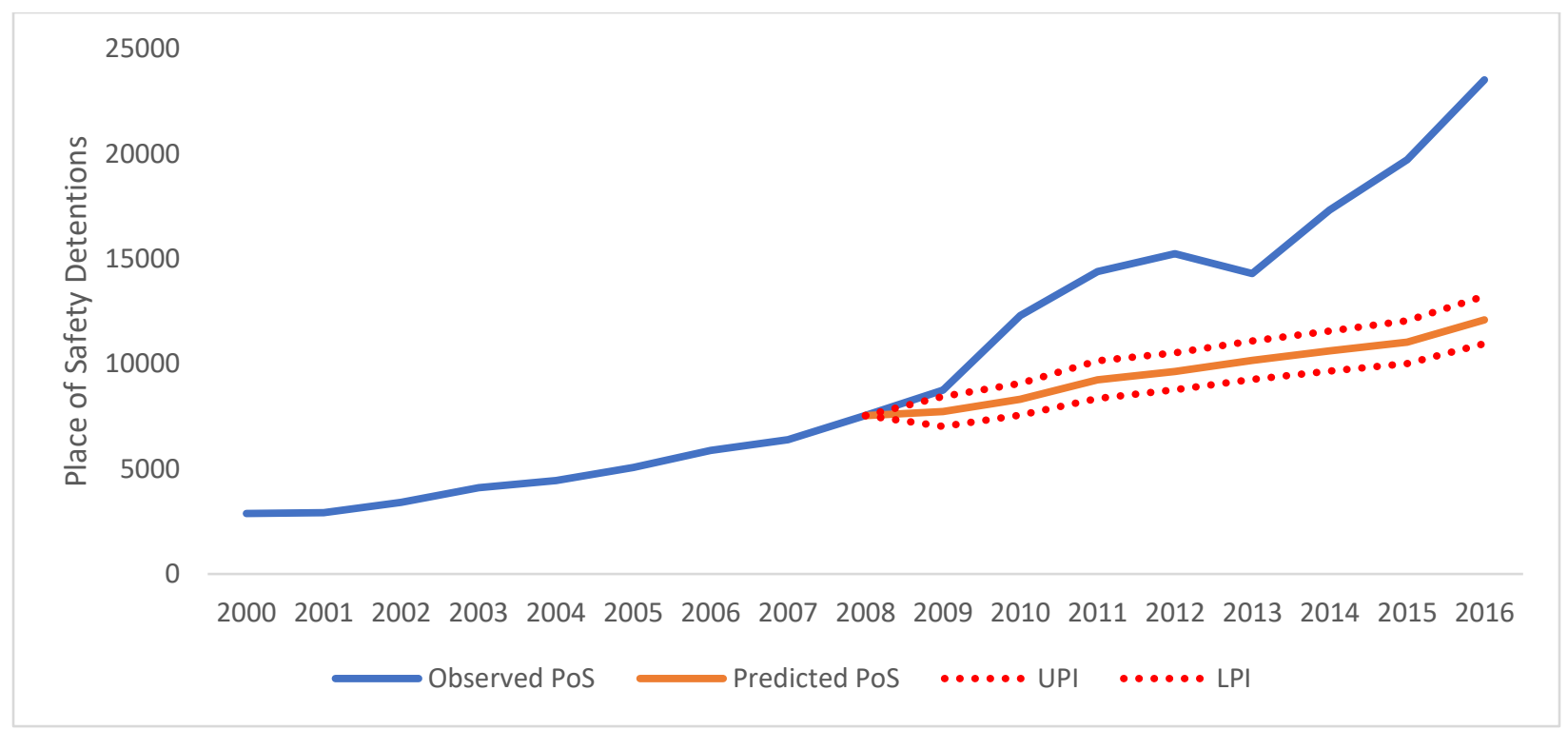

Figure B2: Observed Place of Safety (PoS) detentions in England between 1999/00 to 2015/2016, and predicted rates, adjusted for mental health bed availability between 1999/00 and 2015/16 